\title{
Justification of the concept of development of modern organic agriculture on the basis of biointensive technologies
}

\author{
$V$. A. Kundius* \\ Altai State Agrarian University, Barnaul, Russia
}

\begin{abstract}
The article presents the results of research on the project "Development of organic agriculture based on advanced methods and technologies", with its integrated system approach, models of market organisation, process control of biological function and development of rural areas. The article substantiates the need to develop the concept and programs of organic agriculture in the regions of the Russian Federation in relation to the Altai Territory on the basis of a cluster approach with the development of biointensive technologies, mechanisms and methods of its development.
\end{abstract}

\section{Introduction}

Modern development of agriculture and agroindustrial complex is considered and studied on the basis of a systematic approach from the perspective of socio-ecological-economic processes, which are caused by public health problems, environmental safety, social problems of economic growth in agriculture and rural areas. Organic agriculture development is a modern and strategic trend in the agricultural industry and agribusiness not only in foreign countries, but also in the Russian economy. International Federation of Organic Agriculture Movements (IFOAM) defines organic agriculture as "...a production system that supports the health of soils, ecosystems and people; relies on ecological processes, biodiversity and cycles adapted to local conditions, avoiding the use of resources with adverse consequences. Organic farming combines tradition, innovation and science in favor of a common environment and promoting fair relationships and improving the quality of life for all involved." [1,4]

\section{Materials and Methods}

Results of scientific research reflected in this article are based on the works of Russian and foreign scientists in the field of organic agriculture, normative and legislative acts of the government of the Russian Federation, our own previous works, our own vision of problems and mechanisms for the development of organic agriculture based on an integrated, systematic approach with the use of the methods of systemic strategic analysis, modeling

\footnotetext{
* Corresponding author: kundiusv@mail.ru
} 
economic processes, prospects for the organic products market, forecasting changes and stabilizing the "green" economy.

\section{Results and Discussion}

The growth trends that took place in the formation of the approach to production and consumption of food products are associated with a global increase in the population and the need to meet carbohydrates and protein requirements, micronutrients in accordance with consumption standards. Striving to increase the capacity of agricultural production has led to application of intensive technologies in agriculture based on the active use of mineral fertilizers, plant protection chemicals, GMO seeds, growth hormones, antibiotics, and amplifying of mechanization - to an increase in hydrocarbons consumption, causing harm to the environment. Intensification of agriculture has made significant increasing of the production of agricultural products and supplies possible, reduced their costs and made them more accessible to the general population. However, at the same time, there is an increase in diseases and health problems of consumers of these products. The global environmental problems have become the consequence of intensive agriculture based on chemicalization. Such consequences inevitably necessitated changing of economic growth theories, which began to consider growth problems inseparably from the concepts of "responsible consumption", based primarily on rational nutrition, consumption of environmentally friendly products and healthy lifestyle. With this background, the production of organic agricultural products and food is developing. Currently, organic farming accounts for up to $10 \%$ of traditional agriculture worldwide.

The organic agricultural products market already exceeds 100 billion euros, its annual growth is $10-15 \%[1,2]$, according to the forecasts of All-Russian Scientific Research Institute of Agriculture of RAS, by 2025 it may exceed 200 billion dollars (Fig. 1) [2].

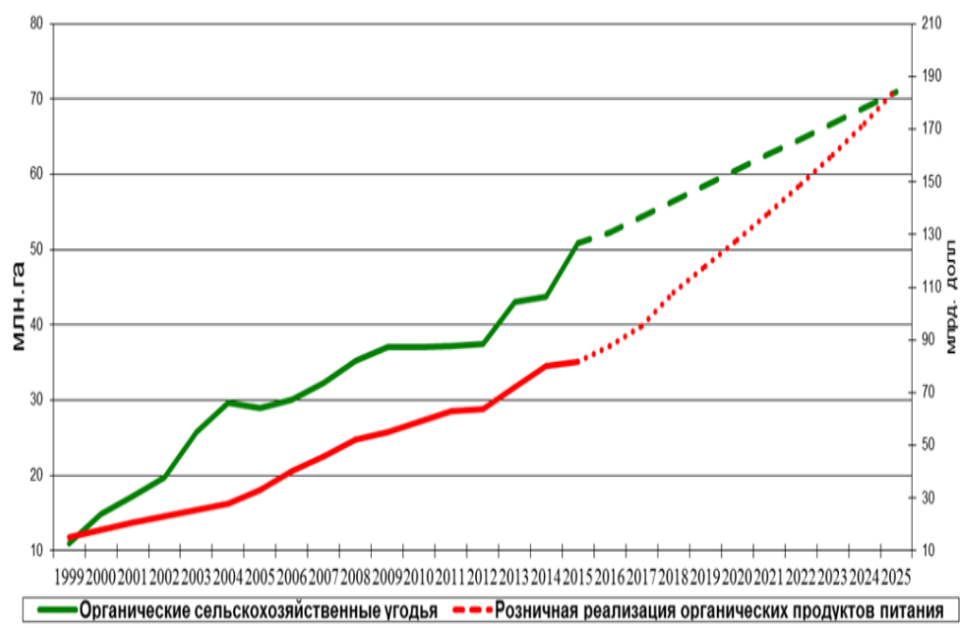

Fig. 1. Forecast of the dynamic pattern in the areas of agricultural land in organic agriculture and the volume of sales of organic food retail.

Where: Hectares Million - млн.га; US Dollars Billion - млрд. Долл.; Organic agricultural land Органические сельскохозяйственные угодья; Retail sale of organic food - Розничная реализация органических продуктов питания; 
The largest share in the production of "organic" agricultural products is occupied by the countries of Alpine and Northern Europe, the Benelux and the Baltic states. In Italy, the share of organic legumes in the total harvested area reached $44.1 \%$. In France, organic leguminous crops are amounted to $26.6 \%$, in Germany the share of organic soybeans is $23.3 \%$, organic sunflower is $13.8 \%$ of the total volume of their production. In Canada, organic vegetable production accounts for $17.2 \%$ of their total production [3]. The structure of sales of organic products by countries of the world is shown in Fig. 2 [3].

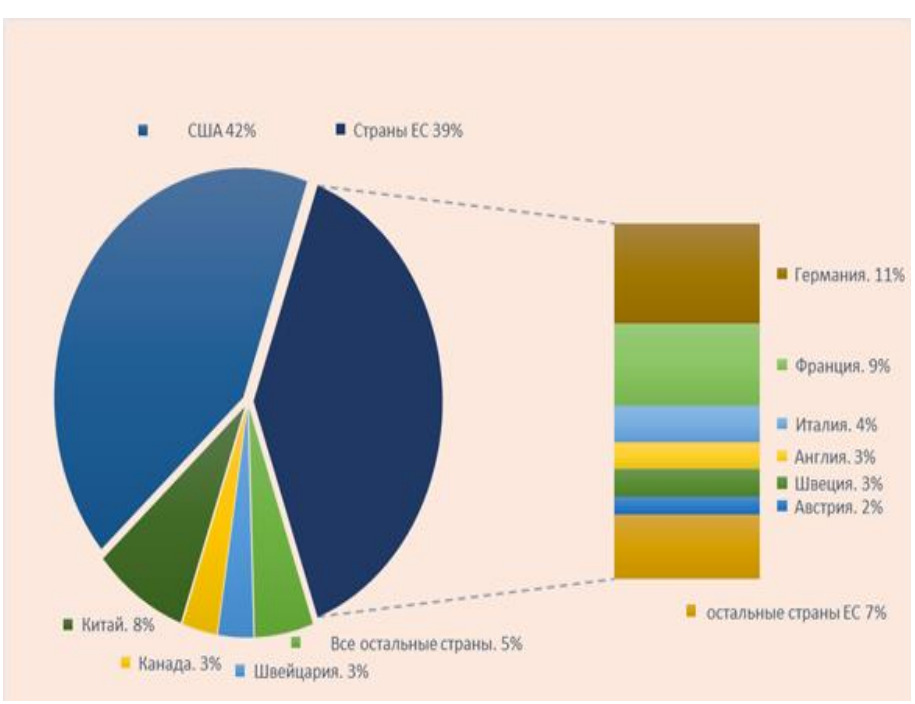

Fig. 2. Structure of sales of agricultural organic products in the world countries in 2018 (\%).

Where: USA - США; Other EU countries - Другие страны EC; China - Китай; Canada - Канада; Switzerland - Швейцария; Germany - Германия; France - Франция; Italy - Италия; Great Britain - Великобритания; Sweden - Швеция; Austria - Австрия;

The studies show that organic farming is becoming a strategic global trend in the development of agroeconomics and the processing industry. However, in the countries of Europe, as well as in North America, the resource potential for organic agriculture is practically exhausted, and there is less and less clean land and water suitable for organic agriculture. At the same time, economists predict an organic farming boom in the next 10 years in countries with a corresponding resource potential, meaning, first of all, Russia. By 2024, according to forecasts, the market volume of environmentally friendly organic products will reach 323 billion dollars [4]. This is due to the fact that organic agricultural production solves problems that classical agricultural production is not able to solve, first of all - social problems - firstly, improving the health of citizens, since the production of organic products in agriculture should not include antibiotics, GMOs, growth hormones, chemical mineral fertilizers, chemical pesticides, herbicides and other aggressive plant protection products, chemical food additives in animal husbandry. Solving environmental problems in organic agricultural production leads to the improvement of soils and, accordingly, an increase in acreage of organic agriculture.

According to experts from the Ministry of Agriculture of the Russian Federation in the countries of the world, Russia is positioned not only as a traditional agricultural food producer, but also as a potential producer and exporter of organic (environmentally friendly) food products, as well as raw materials for the biofuel production (rapeseed, rapeseed oil). At the same time, the land resources of Russia have received increased attention from the world community and transnational corporations. Relatively moderate intensification of agricultural production in previous years, limited use of mineral fertilizers and plant protec- 
tion chemicals, and the ban on GMOs contribute to a faster transition to organic agriculture. Currently, in Russia, the area of unused but suitable for organic farming arable land, according to various estimates is 10-12 million hectares. The amount of pesticides and fertilizers used in our country, according to Corporate Database for Substantive Statistical Data estimates, is on average 16 and 8 times less, respectively, than in the EU [3,5]. In addition, there is a ban on the production of GMOs in Russia at the legislative level. In Russia, despite the unique resource potential and opportunities, there are many unresolved problems and issues for the development of organic agriculture [4, 5, 6, 7]. The Russian market is becoming similar to the European one in terms of production structure. For example, in Europe, fruits, vegetables, cereals and crops are mostly produced, the situation in Russia is the same (Fig. 3).

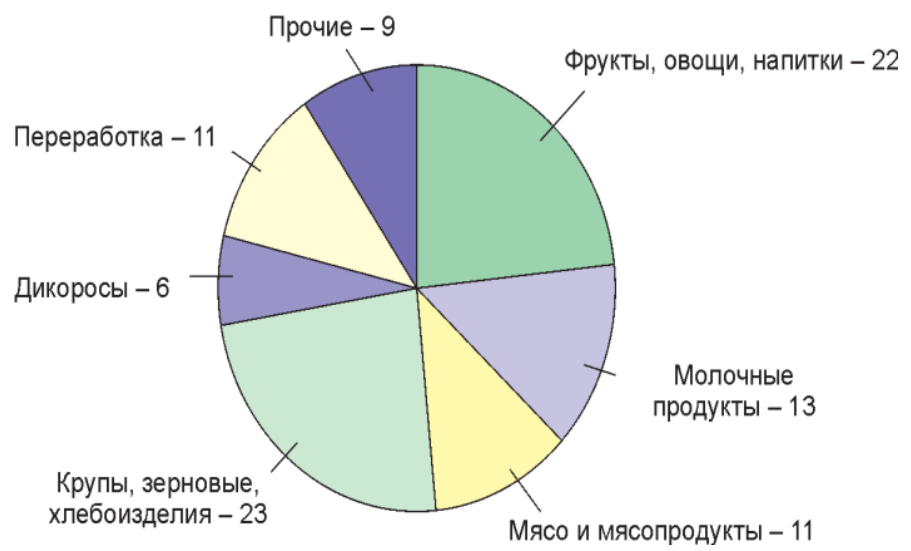

Fig. 3. Production of organic products by type in the Russian Federation, $\%$ [3].

Where: Other -Другие; Fruits, vegetables, beverages - Фрукты, овощи, напитки; Dairy products Молочные продукты; Meat and meat products - Мясо и мясные продукты; Cereals, crops, bakery products - Крупы, зерновые, хлебоизделия; Wild crops - Дикоросы ; Processed products - Переработка.

The production of organic products in Russia focuses primarily on the domestic market. But these opportunities are practically not implemented, since there are many unsolved problems, including those with product certification. According to NeoAnalytics, the capacity of the Russian market for environmentally friendly products is estimated at 300 billion rubles. So far, the market is only $2 \%$ filled and has great growth potential, since, according to experts, the growth in consumption of organic (environmentally friendly) products is more than 2 times higher than the growth rate of the food market as a whole, consumption is far from saturation and will grow as income rises population and reduce the cost of organic products [3].

Our studies in regions of the Altai Territory and the city of Barnaul in 2020, based on a questionnaire, allow us to draw conclusions about the prospects of organic production and the growth of its consumption. Out of 200 respondents $-80.8 \%$ of potential consumers of organic products believe that eating certified organic products undoubtedly has a positive effect on the health of them and their relatives, $68.5 \%$ of respondents are ready to buy organic products even at higher prices. $89.2 \%$ of the 100 surveyed producers of organic products note an increase in demand for environmentally friendly organic products, $91.6 \%$ are ready to produce and offer organic products to their customers.

According to various estimates, the domestic market for organic products ("healthy food") in Russia is estimated at about 900 billion rubles. The scale of the new economy implies at least 15 thousand certified agricultural producers, 3-5 thousand certified pro- 
cessing, trade facilities, etc. For Russia, as a consequence, this means the creation of new jobs with a high level of income in rural areas, the inflow of capital to rural settlements, the development of rural areas, small and medium-sized businesses in the processing, logistics, and trade segments.

Basic conditions for the development of organic agriculture are gradually being created in Russia. First of all, a regulatory and legal framework is being formed: Federal Law No. 280 "On Organic Products and on Amendments to certain Legislative Acts of the Russian Federation" (dated August 3, 2018) was adopted [8]; GOST 33980-2016 "ORGANIC PRODUCTS. Rules for production, processing, labeling and sale"; GOST R 57022-2016 "Organic Products. The procedure for conducting voluntary certification of organic production"; GOST R 56508-2015 "ORGANIC PRODUCTS. Rules for production, storage, transportation"; GOST R 56104-2014 "Organic food products. Terms and Definitions"; Local sectoral program "Organic agriculture" within the priority project "Export of agricultural products".

The "Roadmap for the Development of Organic Agriculture in Russia", developed by the Union of Organic Agriculture in cooperation with the Ministry of Agriculture of the Russian Federation [9], defines the main measures to support organic agriculture within the framework of the government program for 2019-2020, including compensation part of the costs for the accreditation of certification bodies and the certification of organic production itself. Measures have been outlined and carried out to human resourcing the production of organic products, creating a system of education, training and retraining of personnel, scientific and technological support for the production of organic products, a single center of competence, a system of scientific and technological support for the production of organic products - research and development, agrotechnology, standard business plans and agrotechnological maps have been created. Measures to promote the sale of organic products have been outlined, a program to promote organic agriculture products to international markets has been adopted.

The portals of regional bodies of the agro-industrial complex of the section "Organic agriculture" for posting basic information have been created[8].

\section{Conclusion}

Upon that, the development of a system of measures for the development of organic agriculture cannot occur spontaneously everywhere, either in one single enterprise, or throughout the entire territory of the country or region at the same time. In this regard, we have proposed a cluster approach [11] based on the theory of consistency, cooperation, integration, innovative development of organic agriculture. The idea of cluster technologies is to combine the achievement of competitiveness of the participants of cluster formations, cooperation and integration in a geographically limited specialized area. On the scale of the cluster, biointensive technologies, ecosystem management, information support, product certification, market organization and other issues of the development of organic agriculture can be tested.

Among the republics, territories and regions of the Russian Federation, the Altai Territory is one of the few regions that posessses... do not seem to notice the existence of this promising trend in the agriculture development.

Our short-term goals are to refine this document to the level of a strategy (program) for the development of organic agriculture in Altai and Mongolia.

Long-term goals: the possibility of transforming (scaling) this document to the level of the concept (strategy, program) for the development of organic agriculture in the Russian Federation and Mongolia. Organic farming accounts for up to $10 \%$ of traditional agriculture worldwide... 
Sections:

- Promotion of organic agriculture

- System of incentives and promotion of the sale of OA products

- Science and education

- Standardization, certification, government control

- Development of rural areas to establish the "Green Economy" and organic agriculture

- A concept of organizing agricultural markets and zones for the production of organic agricultural products

- Ecosystem management

- Program Development Resources

\section{Acknowledgments}

Scientific research on this topic was carried out with the support of the RFBR project No. 19-510-44011 Mong-t "Development of a concept for the development of organic agriculture based on progressive methods and technologies." We are grateful to the Russian Foundation for Basic Research for financial support of our research.

\section{References}

1. How to support organic farming in Russia? https://www.dairynews.ru

2. Organization of organic agricultural production in Russia, 124 (2018)

3. Organic agriculture: innovative technologies, experience, prospects: scient. analyt. Overview, 92 (2019)

4. Annual consolidated report IFOAM-2017 https://ifoam.bio

5. V. A. Kundius, O. Yu. Voronkova, T.V. Streltsova, T.N. Perova, Agricultural Economics of Russia, 1, 26 (2018)

6. L. Kalyanina, "Expert", 44 (1140) 2019

7. V. A. Kundius, Prospects for the production of environmentally friendly products in the transboundary territories of the Greater Altai, 207 (2016)

8. Federal Law No 280-FZ "On Organic Products and on Amendments to Certain Legislative Acts of the Russian Federation" dated August 3 (2018) http://www.consultant.ru

9. Roadmap for the development of organic agriculture in Russia https://soz.bio

10. V. V. Gorshkov, V. A. Kundius, T. V. Streltsova, Substantiation of the concept of development of organic animal husbandry based on biointensive technologies in the Altai Territory, http://rectors.altstu.ru 